NUREG/CR-4533

SAND86 -7080

RV

Printed March 1986

CONTRACTOR REPORT

$$
\text { RG. } 64279
$$

\title{
Program to Analyze the Failure Mode of Lead-Acid Batteries
}
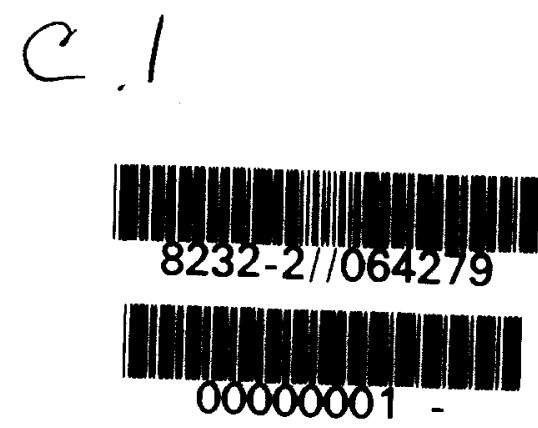

David Zuckerbrod

Westinghouse R\&D Center

1310 Beulah Road

Pittsburgh, PA 15235

Prepared by

Sandia National Laboratories

Albuquerque, New Mexico 87185 and Livermore, California 94550

for the United States Department of Energy

under Contract DE-AC04-76DP00789

Prepared for

\section{U. S. NUCLEAR REGULATORY COMMISSION}




\section{NOTICE}

This report was prepared as an account of work sponsored by an agency of the United States Government. Neither the United States Government nor any agency thereof, or any of their employees, makes any warranty, expressed or implied, or assumes any legal liability or responsibility for any third party's use, or the results of such use, of any information, apparatus product or process disclosed in this report, or represents that its use by such third party would not infringe privately owned rights.

\section{Available from}

Superintendent of Documents

U.S. Government Printing Office

Post Office Box 37082

Washington, D.C. 20013-7982

and

National Technical Information Service

Springfield, VA 22161 
NUREG/CR-4533

SAND 8 6-7080

RV

PROGRAM TO ANALYZE THE FAILURE MODE OF LEAD-ACID BATTERIES

David Zuckerbrod

Westinghouse R\&D Center

1310 Beulah Road

Pittsburgh, PA 15235

Printed: March 1986

Sandia Project Monitor: L. L. Bonzon

work Performed under Sandia contract No. 25-0448

\author{
Prepared for \\ Sandia National Laboratories \\ Albuquerque, NM 87185 \\ Operated by \\ Sandia Corporation \\ for the \\ U.S. Department of Energy
}

Prepared for

Electrical Engineering Instrumentation and Control Branch

Division of Engineering Technology

Office of Nuclear Regulatory Research

U.S. Nuclear Regulatory Commission

Washington, DC 20555

Under Memorandum of Understanding 40-550-75

NRC Fin No.A-1051 
.

. 
PROGRAM TO ANALYZE THE FAILURE MODE OF LEAD-ACID BATTERIES

D. Zuckerbrod

Solid Oxide Technology Venture

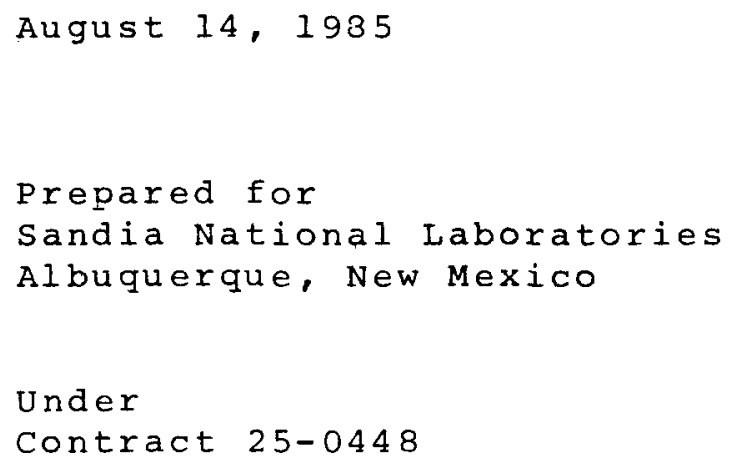

APPROVED:

J.T. Brown, Deputy Venture Manager Solid Oxide Technology Venture

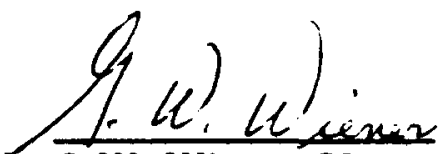

G.W. Wiener, Venture Manager Solid Oxide Technology Venture

\section{Westinghouse R\&D Center} 1310 Beulah Road Pittsburgh, Pennsylvania 15235 


\section{Related Publications in this series}

- L. L. Bonzon and D. B. Hente, "Test Series 1:

Seismic-Fragility Tests of Naturally-Aged Class 1E Gould NCX-2250 Battery Cells," SAND84-1737. NUREG/CR-3923, Sandia

National Laboratories. Albuquerque. New Mexico. September 1984.

- L. L. Bonzon and D. B. Hente, "Test Series 2:

Seismic-Fragility Tests of Naturally-Aged Class IE Exide FHC-19 Battery Cells," SAND84-2628, NUREG/CR-4095, Sandia National Laboratories. Albuquerque, New Mexico, March 1985.

L. L. Bonzon and D. B. Hente, "Test series 3 :

Seismic-Fragility Tests of Naturally-Aged Class IE C\&D LCU-13 Battery Cells," SAND84-2629. NUREG/CR-4096. Sandia National Laboratories, Albuquerque, New Mexico, March 1985.

- L. L. Bonzon and D. B. Hente. "Test series 4:

Seismic-Fragility Tests of Naturally-Aged Exide EMP-13 Battery Cel16." SAND84-2630. NUREG/CR-4097. Sandia National

Laboratories. Albuquerque. New Mexico, March 1985.

- "Seismic-Fragility Baseline Tests of New Class lE Battery Cells." SANDB4-2631, NUREG/CR-4098, Sandia National

Laboratories. Albuquerque, New Mexico. (To be published.)

"Age-Related Degradation of Naturally-Aged Class lE Battery Cells," SAND84-2632, NUREG/CR-4099, Sandia National

Laboratories. Albuquerque. New Mexico. (To be published.)

- "Seismic-Fragility Tests of Accelerated-Aged Class IE Battery Cells". Sandia National Laboratories, Albuquerque, New Mexico. (To be published.)

Comparison of Naturally-Aged and Accelerated-Aged Class IE Battery Cells: An Evaluation of the Aging Method". Sandia National Laboratories, Albuquerque, New Mexico... (To be published.) 
SOLID OXIDE TECHNOLOGY VENTURE

Report 85-9V11-SPONE-R1

\title{
PROGRAM TO ANALYZE THE FAILURE MODE OF LEAD-ACD BATTERIES
}

\author{
by \\ D. Zuckerbrod
}

\begin{abstract}
The electrical characteristics of large lead-acid cells from nuclear power plants were studied. The overall goal was to develop non-destructive tests to predict cell failure using this easily obtained information. Cell capacitance, internal resistance, reaction resistance for bydrogen evolution and cell capacity were measured on a lead-calcium cell in good condition. A high float voltage and low internal resistance were found to correlate with good cell capacity in cells selected from a set of six lead-antimony cells in poor cordition.
\end{abstract}




\section{Table of Contents}

\section{$\underline{\text { PAGE }}$}

1. SUMMARY $\ldots \ldots \ldots \ldots \ldots \ldots \ldots \ldots \ldots \ldots \ldots \ldots \ldots \ldots \ldots \ldots$

2. RECOMMENDATIONS $\ldots \ldots \ldots \ldots \ldots \ldots \ldots \ldots \ldots \ldots \ldots$

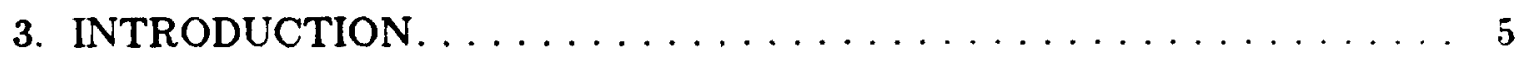

4. EXPERIMENTAL RESULTS $\ldots \ldots \ldots \ldots \ldots \ldots \ldots \ldots$

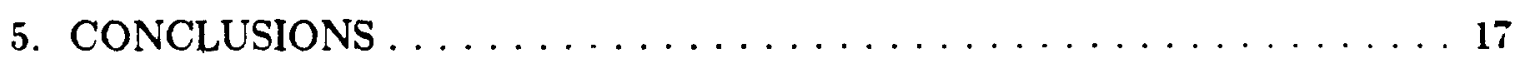

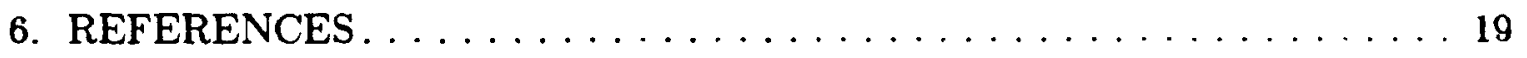




\section{List of Figures}

PAGE

4-1. Polarization Profile - Cell \#8 $\ldots \ldots \ldots \ldots \ldots \ldots \ldots \ldots \ldots \ldots 11$ 


\title{
STUDY BACKGROUND
}

\author{
Lloyd L. Bonzon \\ Sandia National Laboratories
}

Sandia National Laboratories is currently under contract to the United states Nuclear Regulatory Commission to study the degradation and failure modes of Class lE, safety-related. equipment used in nuclear power stations. One aspect of the effort is the interest in the significance of aging and the subsequent survivability of stationary emergency power batteries when exposed to a simulated seismic event.

The list of "Related Publications in This series" is indicative of the overall program goals:

- To determine seismic failure modes and thresholds, primarily using naturally-aged cells.

- To select the dominant aging mechanism(s) through this testing experience, other test experience, and expert evaluations.

- To compare the response of naturaliy-aged cells to the response of new cells aged by the accelerated methods described in IEEE std. 535-1979 and compare dominant failure modes in both cases.

- To determine appropriate accelerated aging methodologies for the dominant failure mode(s).

- To demonstrate those accelerated aging methodologies through a specific demonstration test program.

- To make final recommendations for appropriate accelerated-aging methodology(ies) for nuclear station batteries.

- To develop in situ testing methods that can predict the remaining age and seismic "tolerance" of batteries.

The study documented in this report is aimed at the last goal. and represents an initial attempt to assess battery cell "condition" through a correlation (and model) of cell output with its electrical characteristics. A result may be a nondestructive test(s) that could predict cell susceptibility to seismic-induced accelerations.

It is important to realize that this study was limited in scope to simply investigate the potential for such correlation. The available samples and the economic realities preclude a more thorough study and definitive conclusions at this time. However. 
it is also important that the work done to date be reported so

that it receive peer dissemination and be available to serve as a bases for other similar efforts. independent of how they are pursued in the future or by whom. 


\section{SUMMARY}

While the failure modes of lead-acid cells are extensively described in the literature, failure under actual use conditions is difficult to predict by mathematical modeling alone due to the complexity of their individual histories. The ultimate goal of this program was to identify, validate and integrate various nondestructive testing techniques into a simpie go/no-go test for determining when lead-acid cells should or must be replaced in nuclear power plants before failure occurs.

A total of seven specimens were examined; one lead-calcium cell, approximately 12 years old and in substantially good condition, and six leadantimony cells, about 12 years old and severely decayed in performance. The lead-calcium cell was examined in detail. Cell capacitance, internal resistance, polarization profile and 8 and $3 \mathrm{hr}$. rate capacity were measured. Three plate tests were run on representative plates as well. The data obtained provided baseline information on a cell in substantially good condition.

The six lead-antimony cells had been damaged by chronic overcharging due to an error in their maintenance specification. Their internal resistance, float voltage, and reaction resistance for gassing were measured. Capacitance measurement were elusive due to the extreme degradation of the cells. Predictions of cell capacity on the basis of float voltage and internal resistance correlated qualitatively with the cells' actual $8 \mathrm{hr}$. capacity, the "good" cell having a $42 \%$ of nameplate capacity and the "bad" cells having a $10 \%$ and 7\% capacity. On this basis, it is felt that the first phase of this program has been successful in identifying easily measured parameters which are indicative of cell condition (capacity). 


\section{RECOMMENDATIONS}

- Obtain several new, used and failed lead calcium cells and examine their electrical properties to verify and extend the performance model.

- Specify and perform a simple on-site battery analysis on a bank of installed cells and correlate with deep discharge test records.

- Compile the above information and recommend a non-destructive go/no go test for large lead acid cells.

- The data and information gathered in this initial phase of the work should be expanded to investigate a broader sample base for analysis. At this point there is a reasonably high probability that a predictive model for these cells in this mission can be established and defined in detail. 


\section{INTRODUCTION}

Lead-acid batteries fail, in general, from one of three main causes (in order of their frequency):

1. Expansion of the positive grid,

2. Loss of active material from the positive plate (other than that due to positive grid expansion), and

3. Loss of capacity due to changes in the morphology of the active material of the positive plate.

The first failure mode, expansion of the positive plate, is the most prominent mode of failure of a lead-acid battery on the nearly constant float duty of an emergency power source. The first studies published on this system were done by Willihnganz ${ }^{1}$ and Cannone and coworkers ${ }^{2}$ in the late 1960's. This work concluded that the rates of conversion of the positive grids to lead oxide and the concomitant expansion of the plates for lead, lead-antimony, and lead-calcium grids are exponential with temperature. This exponential relationship arises because the rate of the corrosion is activation-energy controlled and the corrosion rate therefore follows an Arrhenius-type relationship, ${ }^{3}$

$$
I_{\text {corr }}=I^{*} \exp \left(-E_{c} / R T\right)
$$

where $E_{c}$, the activation energy for corrosion, is approximately $10.5 \mathrm{kcal} / \mathrm{mole}$ for lead-calcium grids.

The expansion of the positive grid causes the loss of active material due to loss of electrical contact between the grid and the active material and therefore a loss in capacity. The conversion of the grid to the oxide also manifests 
itself as an increase in plate resistance or impedance, and strain on the battery case due to the volume increase of the positive plate. The combination of these effects will contribute in varying degrees to the eventual failure of the cell. Work at Westinghouse by Maskalick ${ }^{4}$ in the early 1970's showed that the rate of failures as defined by a loss of capacity and the corrosion of the positive plate also increases with the number of discharge cycles and the depth of discharge as well as with temperature.

The second mode of failure of the lead-acid battery is due to shedding, the loss of electronic contact between the active material and the positive grid. Excessive gassing, frequency of cycling, and expansion of the positive plate all contribute to shedding. However, this failure mode is not solely due to positive grid corrosion, and therefore tests based only on positive plate corrosion could incorrectly predict too long a lifetime for a cell which fails due to shedding.

The third type of failure is due to morphological changes in the active material of the positive plate arising from discharging the battery while utilizing a pulse waveform rather than being in a DC mode. (As an example, power conditioning equipment may require that the battery be discharged in pulses rather than continuously). A study by MERADCOM ${ }^{5}$ compared the effect of continuous discharge on a plate with the effect of pulsed ( 3 millisecond) discharge. They found significant coarsening of the active material of the positive plate in the pulse-discharged batteries as compared to that of the constantly discharged cells. Again, the time-temperature relation for prediction of cell life would not be applicable to this failure mode as the mechanism of failure is not following the rate-temperature relationship described by Equation 1.

The interactions of the various use components in the emergency power system,

- the float voltage,

- the power output,

- whether ripple is imposed on the cells,

- the frequency of discharge, and 
- the depth of discharge

all affect the life of the battery in more complex ways than the positive grid expansion tests allow for or are capable of identifying using the present procedures. Therefore, new, nondestructive procedures must be developed to predict what aging processes are occurring and how they will affect the performance and lifetime of the cell with time.

The overall goal of the program, as we view it at Westinghouse, is to develop and validate a less costly, less intrusive, and more dependable procedure for checking the condition of large lead-acid cells. The work centered around the correlation of cell condition (Amp-hour capacity and V-I performance) with the cell's electrical characteristics (capacitance, electronic resistance, and reaction resistance for gas evolution, and float voltage).

The batteries of interest tend to have an enormous electrical capacitance (not to be confused with amp-hour capacity). For the large cells in this study, it tends to be in the range of 1000 farads. The cell's capacitance is proportional to the real surface area of the interface between the active materials on the plate and the electrolyte. This capacitance is measured by applying a charge current step of about 1 amp to a fully charged cell while recording the cell's voltage response to this perturbation as a function of time. A lower than expected capacitance will probably be indicative of a failure mode involving shedding, plugging of pores due to morphological changes, or exfoliation from the current collector grid.

The electronic resistance of the cell is interpreted as a measure of the condition of the current collector grids, the integrity of the busses, and the attachment of the active material to the grid. A high electronic resistance, as measured by a current interruption technique, would indicate failure by the above modes rather than by those which would be indicated by a low measured capacitance.

The reaction resistance for gas evolution is an independent measure of the extent of "poisoning" of the cell with deposits of low overvoltage impurities on the plates. Excessive gassing hastens cell failure by dislodging active material 
from the plates, resulting in a low amp-hour capacity. It also increases make-up water and float current requirements. The reaction resistance is obtained from the change in steady-state voltage resulting from a step change in float current. This, along with long term records of float current and voltage should give a better picture of the cell's condition on float charge. The goal of this phase of the program was to identify and quantify how these parameters can be used to monitor the aging of the cell in a nondestructive manner. The overall goal for the program is the development of a simple go/no-go test for use in determining when the lead-acid cells should be replaced in the nuclear plant before failure occurs while still maintaining the ability to perform the mission. 


\section{EXPERIMENTAL RESULTS}

The first cell, designated as cell \#8, from Ontario Hydro, arrived at the R\&D Center on October 24, 1984. It was a Gould lead-calcium cell, type NCX-2250. It was immediately noted that the packing materials were wet with acid, indicating a possible leak due to transportation. The cell was uncrated the next day and it was ascertained that the cell was leaking slowly through the bottom face. The skid was twisted off-square indicating that some impact had occurred. The leak was slow enough that the electrolyte never dropped below the tops of the plates. A repair was attempted as follows. A Lucite ${ }^{T M}$ tray was built. The cell bottom was neutralized with sodium bicarbonate, then $3 \%$ ammoniawăter and finally it was washed with deionized water and dried. The Lucite ${ }^{\text {TM }}$ tray was covered with 5 minute Epoxy-Patch ${ }^{\mathrm{TM}}$ and the cell was slid into it. Finally the tray was filled with a 24-hour epoxy type potting material and was left to cure over the weekend. Unfortunately the leaking acid prevented the proper curing of the epoxy and the cell has continued to leak. For safety, the cell was placed in a larger tray, which can be emptied periodically.

The electrical current requirements for cell charging and discharging was provided by two $500 \mathrm{~A}, 10 \mathrm{~V}$ regulated power supplies, wired in parallel. A resistive load bank was used to sink the cell energy during discharge with the power supplies providing the current regulation. Cell voltage was measured at the terminals with a $31 / 2$ digit voltmeter, cell current was measured by a $1000 \mathrm{~A}$, $50 \mathrm{mV}$ meter shunt and a $41 / 2$ digit voltmeter. A permanent record of cell current and voltage was provided by a two-pen chart recorder.

Due to the leak in the cell, additions of electrolyte were made as needed. The make-up electrolyte was always adjusted to the specific gravity of the cell at the time of addition. This may still lead to ambiguities over the absolute meaning of specific gravity measurements as the cell is no longer a closed system with respect to $\mathrm{SO}_{4}^{-2}$. However, addition of electrolyte was the only practical method of cell maintenance short of replacing the cell case. 
The specific gravity of the electrolyte in the cell as received was 1.135. The cell was then given the specified "equalizing charge" to $2.45 \mathrm{~V}$. The specific gravity increased to 1.225 . Float current at $2.32 \mathrm{~V}$ was $\sim 0.5 \mathrm{~A}$. After 6 days on float the cell was discharged at 700A. The capacity to $1.75 \mathrm{~V}$ was $1458 \mathrm{Ah}$ which is $92 \%$ of the manufacturer's specification of $1590 \mathrm{Ah}$ for this rate. The electrolyte temperature increased from $25^{\circ} \mathrm{C}$ to $30^{\circ} \mathrm{C}$ during the course of this high current discharge. The discharge was continued further to $1.50 \mathrm{~V}$ and this yielded an additional $374 \mathrm{Ah}$ to give a total capacity of $1832 \mathrm{Ah}$. The cell was then recharged and floated for 7 days. The specific gravity of the electrolyte reached 1.210. A second discharge at $280 \mathrm{~A}(8 \mathrm{hr}$. rate) gave $2287 \mathrm{Ah}$ or $102 \%$ of the rated capacity of the cell.

The internal resistance of cell \#8 was measured by a current interruption technique at currents up to 50A. This consisted of interrupting the cell discharge current using a fast $(1 \mu \mathrm{sec})$ electronic switch and observing the instantaneous rise in voltage using a oscilloscope triggered by the switch. The cell contained 1.225 Sp. Gr. electrolyte, was fully charged, and had been floated at $2.30 \mathrm{~V}$. The internal resistance was $.28-31 \mathrm{~m} \Omega$, measured repeatedly at various currents. A polarization profile was recorded from $138 \mathrm{~A}$ to $600 \mathrm{~A}$ and back again. (Figure 4-1). The dwell time at each point was 1 minute. The almost linear shape of the curve suggested that the cell voltage was under resistance control in this current range. This would be expected for a fully charged cell in good condition.

The specific gravity of the electrolyte was then adjusted to 1.235 , the actual plant operating condition. The three-hour capacity (585A to $1.75 \mathrm{~V}$ ) was 1835 Ah or $106 \%$ of the rated capacity. A mercury/mercurous sulfate reference electrode was used to measure separate electrode potentials. It was thereby ascertained that the cell capacity was limited, as expected, by the positive electrodes.

$\mathrm{AC}$ and transient techniques can yield the diagnostic information on large cells without the need for lengthy, life-shortening deep discharges. The goal is to establish a simple, practical test to determine electronic resistance, double layer capacitance, and reaction resistance for local action under float conditions. 


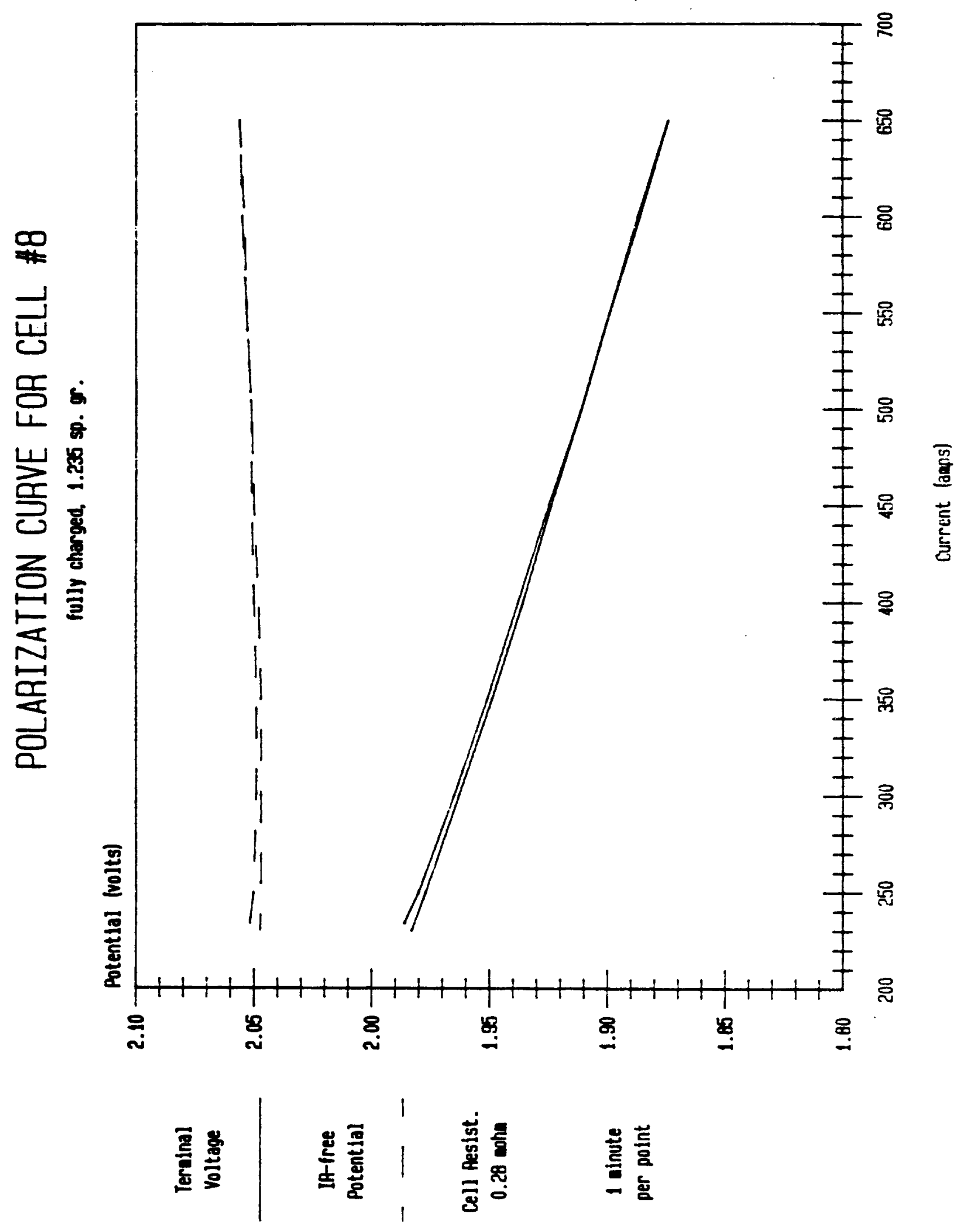

Figure 4-1. Polarization Profile - Cell \#8. 
The fully charged state has been chosen for study as any other condition would require the rapid modulation or interruption of large currents with difficulties related to the inductance of the circuit. As a first attempt, the equivalent circuit has been designated as:

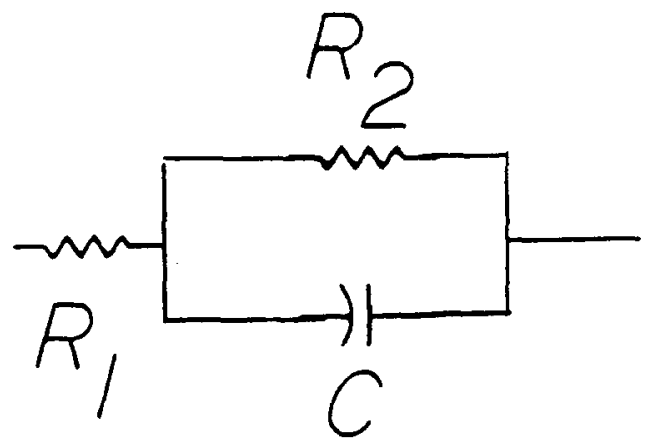

where $R_{1}$ represents the electronic resistance of the cell, $R_{2}$ the reaction resistance, and $C$, the cell capacitance. The time constant of the cell, $\tau$ was determined to be $45 \mathrm{sec}$ by imposing a current step and recording the initial slope of the voltage response with time.

$$
\frac{1}{\tau}=\frac{1}{\Delta V}\left(\frac{d V}{d t}\right)_{t=0} .
$$

The reaction resistance was determined to be $41 \mathrm{~m} \Omega$ by dividing the change in the steady-state voltage due to the current step by the magnitude of the step.

$$
R_{2}=\frac{\Delta V}{\Delta i}
$$

where $\Delta \mathrm{V}$ is the change in steady-state voltage in response to a current step $\Delta \mathrm{i}$. The electronic resistance had been previously determined to be $0.3 \mathrm{~m} \Omega$. From this, the cell capacitance $(C)$ can be calculated to be approximately 1100 Farads. 


$$
C=\frac{\tau}{R_{2}} \text { where } R_{2} \gg R_{1}
$$

From this value, and the rule of thumb that aqueous double layer capacitance is on the order of $40 \mu \mathrm{F} / \mathrm{cm}^{2}$, it can be inferred that the electrochemical surface area of the cell is approximately $\mathbf{7 5 0}$ times the geometric area of the plates.

The next portion of the work dealt with the study of the condition of individual plates. The top of the cell was removed to expose the busses and tops of the plates. It was decided that more meaningful capacity measurements would be made if the cell geometry was not disturbed by disassembly and re-assembly into individual 3-plate cells. So the current busses were cut to yield four 3-plate cells, two positive limited ( 1 positive plate, 2 negative plates) and two negative limited (the reverse). One of each was outboard of the cell posts and one each was between the posts. The capacities were measured at the presumed 3-hour rate with each cell charged and discharged individually, while the rest of the cell was fully charged and on open circuit. While this data may not be exactly comparable to the discharge data for the whole cell, i.e., the specific gravity of the bulk electrolyte remains high, it is felt that the capacity data is still valid and can give an accurate comparison of the capacities of individual plates in the cell. Single plate capacities for this 31-plate cell are nominally the total capacity divided by 15 , or at the three hour rate, $1755 / 15$ or $117 \mathrm{Ab}$. The capacities measured were as follows:

\section{Position}

center

outboard

center

outboard

\section{Polarity}

pos.

pos.

neg.

neg.
Capacity (Ah)

181

155

187

152

The capacities showed considerable difference between plates at the center and plates toward the outside of the cell. This may be due to differences in acid concentration arising from geometric effects on electrolyte convection.

The next group of cells were obtained from the Duquesne Light Beaver 
Valley Plant on January 8, 1985. They consisted of 6 Gould NAX-1800 leadantimony cells, which were about 12 years old. They had been chronically overcharged due to an error in their maintenance specification. They were wired in series and placed on float charge. All cell cases arrived intact with no acid leakage.

The string was given "equalizing" charge at $2.24 \mathrm{~V}$ per cell for three days preceeding the measurements below.

The electronic resistance of the cells, reaction resistance for hydrogen evolution and float voltage are tabulated below. The reaction resistance was calculated as $\mathrm{R}_{\mathrm{r}}=\left(\mathrm{E}_{5 \text { Amps }}-\mathrm{E}_{2.2}\right.$ Amps $) / \Delta \mathrm{I}_{(2.8 \mathrm{Amps})}$.

\begin{tabular}{|c|c|c|c|}
\hline Cell & $\begin{array}{c}\text { Electronic } \\
\text { Resistance } \\
\quad \underline{m} \Omega\end{array}$ & $\begin{array}{l}\text { Reaction } \\
\text { Resistance } \\
\quad \underline{\mathbf{m} \Omega}\end{array}$ & $\begin{array}{l}\text { Float } \\
\text { Voltage } \\
(\mathbf{2 . 2 A})\end{array}$ \\
\hline$\overline{14}$ &.$\overline{.44}$ & $\overline{10.71}$ & 2.156 \\
\hline 15 & .30 & 11.07 & 2.158 \\
\hline 23 & .38 & 11.43 & 2.161 \\
\hline 25 & .30 & 9.64 & 2.161 \\
\hline 28 & .48 & 10.36 & 2.157 \\
\hline 50 & .46 & 3.96 & 2.178 \\
\hline
\end{tabular}

An initial attempt to measure cell capacitance was unsuccessful as the voltage response to a current step did not follow a logarithmic curve as predicted from the previous model.

A second attempt was made to measure the capacitance of several of the NAX-1800 cells obtained from the Duquesne Light Beaver Valley Plant. In each case, the voltage response from a step change in charging current did not fit the previous model proposed for the lead-calcium cells. This can be attributed to non-uniformity of resistance and/or capacitance across the plate. This gives rise to a variety of time constants not previously seen in the lead-calcium cell, which was in substantially good condition. These varying time constants are seen electrically as an average which cannot easily be interpreted.

Another reason for the non-ideal electrical behavior of these cells, as 
compared to the lead-calcium cells, would be that the excessive gassing of these cells disturbs the electrical "double layer" at the surface of the plates, preventing interpretation of the $\mathrm{V}$ vs. time curve. This excessive gassing is indicated by a float current of $1.48 \mathrm{~A}$ for 2.17 volts per cell as opposed to $.45 \mathrm{~A}$ for 2.30 volts on the lead calcium cell.

The cells which were to be checked for capacity were selected on the basis of their float voltage and internal ohmic resistance, i.e., high float voltage and low internal resistance indicated a good cell. At the 3 hour rate (468 amps), cell voltage immediately fell below the 1.75 volt cut-off. The cells were therefore discharged at the 8 hour rate (225 amps) to a 1.75 volt cut-off. The results are shown below.

\begin{tabular}{lccccc} 
Cell & $\begin{array}{c}\text { Float Voltage } \\
(\mathbf{V}) \text { at 1.48A }\end{array}$ & $\begin{array}{c}\mathbf{R}_{\text {ohmic }} \\
\mathbf{m} \Omega\end{array}$ & $\begin{array}{r}\mathbf{R}_{\text {react }} \\
\mathbf{m} \Omega\end{array}$ & \multicolumn{2}{c}{ Capacity } \\
& & & & & \\
14 & 2.150 & .44 & 10.7 & 187 & 10.4 \\
25 & 2.162 & .30 & 9.6 & 764 & 42.4 \\
30 & 2.150 & .46 & 3.9 & 125 & 7.0
\end{tabular}

The resultant capacity measurements $(\mathrm{Ab})$ indicate that high ohmic resistance and low float voltage correlate with poor discharge capacity as originally expected in the selection process, while reaction resistance, essentially the slope of the polarization (I vs. E) curve for gas evolution, does not reliably predict cell condition for these particular cells. This is not a generalized conclusion but should be extended to determine the validity of the assumptions as they relate to capacity and ability to perform the power plant mission. 


\section{CONCLUSIONS}

Float voltage and internal resistance appear to predict cell capacity, at least in a relative sense. Low float voltage and high internal resistance correlate with poor capacity. Measurement of float voltage is essentially a non-invasive procedure, having no effect on the cells. Internal resistance can be measured by interrupting a modest (50 amp) current. This procedure is far less energy intensive and less damaging to the cells than the present deep cycling procedure for determination of actual cell capacity. While, due to the limited number of tests performed, it is difficult to draw a firm conclusion as to specific values for pass or fail criteria, the evidence points to the value of these simple tests in the prediction of cell failure.

The reaction resistance for gas evolution did not correlate with cell capacity. This may be due to the nonlinearity of the V-I curve in the gas evolution region. A more detailed analysis of this curve would be required to establish this parameter rather than a simple calculation of an arbitrary $\frac{\Delta V}{\Delta I}$ value.

Cell capacitance was difficult to measure in the lead-antimony cells. This may be due to their very poor condition giving rise to non-uniformities not accounted for by a simple equivalent circuit model. The inherently low overvoltage for hydrogen evolution for lead-antimony cells may have contributed to this behavior. The capacitance of the lead-calcium cell was in the range expected for this type of device. No specimen was available for comparison; however, thus no conclusion can be reached regarding its correlation with cell capacity.

Thus, with the correlation of two-cell electrical parameters, float voltage and internal resistance, with cell capacity, it is felt that the goals of this phase of the project have been met. Additional work will be necessary to develop a statistical basis for the correlation. Examination of more specimens will be 
necessary to determine if cell capacitance also would be a useful parameter in the development of a simple, rapid, benign qualification test for large lead-acid cells used in nuclear power plants. 


\section{REFERENCES}

1. E. Willihnganz, Electrode. Technology, Vol. $\underline{6}, 1968$, pp. 338.

2. A.G. Cannone, D.O. Feeder, and R.V. Biagetti, Bell System Tech. J., Vol. $\underline{49}, 1870$, pp. 1279.

3. P.C. Milner, Bell System Tech. J., Vol. $\underline{49}$, 1970, pp. 1321.

4. N.J. Maskalick, J. Electrochem. Soc., Vol. 122, 1875, pp. 19.

5. U.S. Army Mobility Equipment Research and Development Command (MERADCOM), Tech. Report ANL/OEPM-83-1, Argonne National Laboratory, 1983. 
U.S. Government Printing office Receiving Branch (Attn: URC Stock) 8610 Cherry Lane

Laure I, ED 20707

375 copies for RV

Ansaldo Impianti

Centro Sperimentale del Boschetto

Corso F.M. Perrone, 118

16161 Genova

ITALY

Attn: C. Bozzolo

Ansaldo Impianti

Via Gabriele D'Annunzio, 113

16121 Genova

ITALY

Attn: S. Grifoni

ASEA-ATOM

Department KRD

Box 53

S-721 04

Vasteras

SWEDEN

Attn: A. Kjellberg

ASEA-ATOM

Department TQD

Box 53

S-72104

Vasteras

SWEDEN

Attn: T. Granberg

ASEA KABEL AB

P.O. BOX 42108

S-126 12

Stockholm

SWEDEN

Attn: B. Dellby

Atomic Energy of Canada, Ltd.

Chalk River Nuclear Laboratories Chalk River, Ontario KOJ $1 \mathrm{JO}$

CANADA

Attn: G. F. Lynch
Atomic Energy of Canada, Ltd. 1600 Dorchester Boulevard West Montreal, Quebec H3H IP9 CANADA

Attn: S. Wish

Atoric Energy Research Establishment Building 47, Division M.D.D.

Harwell, Oxfordshire

OX11 ORA,

EUGLAND

Attn: S. G. Burnay

Bhabha Atomic Research Centre

Health Physics Division

BARC

Bombay-85

INDIA

Attn: S. K. Mehta

British Nuclear Fuels Ltd.

Springfields Works

Salwick, Preston

Lancs

ENGLAND

Attn: W. G. Cunlife, Bldg 334

Brown Boveri Reaktor GMBH

PostEach 5143

D-6800 Mannheim 1

WEST GERMANY

Attn: R. Schemmel

Bundesanstalt fur Materialprufung Unter den Eichen 87

D-1000 Berlin 45

WEST GERMANY

Attn: $K$. Wundrich

CEA/CEU-FAR

Departement de Surete Nucleaire

Service d'Analyse Fonctionnelle

B.P. 6

92260 Fontenay-aux-Roses

FRANCE

Attn: M. Le Meur

J. Henry 


\section{CERy}

Laboratorie 1

CH-1211 Geneve 23

SWITZERLAND

Attn: H. Schonbacher

Canada Wire and Cable Limited Power \& Control Products Division 22 Commercial Road

roronto, Ontario

CANADA HAG 124

Attn: Z. S. Panici

Centro Elettrotecnico

Sperimentale Italiano

Research and Development

Via Rubattino 54

20134 Milan,

ITALY

Attn: Carlo Masetti

Commissariat a l'Energie Atomique ORIS/LABRA

BP $\mathrm{A}^{\circ} 21$

91190 Gif-Sur-Yvette

FRANCE

Attn:

G. Gaussens

J. Chenion

F. Carlin

Comaissariat a l'Energie Atomique CEN Cadarche DRE/STRE

BP $\mathrm{u}^{\circ} 1$

23115 Saint Paul Lez Durance FRANCE

Attn: J. Campan

Conductores Monterrey, S. A.

P. O. Box 2039

Monterrey, $\mathbf{X}$. L.

MEXICO

Attn: P. G. Murga

Electricite de France

(S.E.P.T.E.U.)

12, 14 Ave. Dubrieroz

69628 Villeurbarnie

Paris, FRANCE

Attn: H. Herouard

H. Hermant
Electricite de Erance

Direction des Etudes et Recherches

1. Avenue du General de Gaulle

92141 CLAMAART CEDEX

ERANCE

Attn: J. Roubault

L. Deschamps

Electricite de France

Direction des Etudes et Recherches

Les Renardieres

Boite Postale $n^{\circ} 1$

77250 MORET SUR LORING

FRANCE

Attn: Ph. Boussarie

V. Deglon

J. Ribot

Energia Nucleare e delle

Energie Alternative

CKE Casaccia

1-0060 Rome

ITALY

Attn: A. Cabrini

EURATOM

Commission of European Communities

C.E.C. J.R.C.

21020 Ispra (Varese)

ITALY

Attn: G. Mancini

ERAMATOME

Tour Fiat - Cedex 16

92084 Paris La Defense

FRANCE

Attn: G. Chauvin

E. Raimondo

Furukawa Electric Co., Ltd.

Hiratsuka Wire Works

1-9 Higashi Yawata - 5 Chome

Hiratsuka, Kanagawa Pref

JAPAN 254

Attn: E. Oda

Gesellschaft fur Reaktorsicherheit (GRS) mbH Glockengasse 2

D-5000 Koln 1

WEST GERMANY

Attn: Library 
Health $c$ safety Executive Thames House vorth

Milbank

London SWIP AQJ

ENGLAND

Attn: W.W. Ascroft-Hutton

ITT Cannon Electric Canada

Four Cannon Court

Whitby, Ontario LIA 5 V8

CANADA

Attn: B. D. Vallillee

Imatran Voima oy

Electrotechn. Department

P.O. Box 138

SF-00101 Helsinki 10

FIRLAND

Attn: B. Regnell

K. Koskinen

Institute of Radiation Protection Department of Reactor Safety

P.O. Box 268

00101 Helsinki 10

EINLAND

Attn: L. Reiman

Instituto de Desarrollo y Diseno

Ingar - Santa Fe

Avellaneda 3657

C.C. $34 \mathrm{~B}$

3000 Santa Fe

REPUBLICA ARGENTINA

Attn: $\mathbf{X}$. Labath

ISHES S.P.A.

Viale G. Cesare, 29

24100 BERGAMO, Italy

Attn: A. Castoldi

M. Salvetti

Japan Atomic Energy Research Institute Takasaki Radiation Chemistry

Research Establishment

Watanuki-machi

Takasaki, Gunaa-ken

JAPAN

Attn:

d. Tamura

K. Yoshida

T. Seguchi
Japan Atomic Energy Research Institute Tokai-kura

Naka-Gun

Ibaraki-ken

319-11, JAPAN

Attn: $Y$. Koizumi

Japan Atomic Energy Research Institute Osaka Laboratory for Radiation Chemistry 25-1 Mii-Minami machi.

Meyagawa-shi

Osaka 572

JAPAN

Attn: $Y$. Nakase

Kalle Miederlassung der Hoechst $A G$ Posteach 3540

6200 Wiesbaden 1 , WEST GERMANY

Biebrich

Attn: Dr. H. Wilski

Kraftwerk Union AG

Department R361

Hammerbacherstrasse $12+14$

D-8524 Erlangen

WEST GERMANY

Attn: I. Tercy

Kraftwerk Union AG

Section R541

Postfach: 1240

D-8757 Karlstein

WEST GERMANY

Attn: $W$. Siegler

Kraftwerk Union AG

Hammerbacherstrasse $12+14$

Postfach: 3220

D-8520 Erlangen

WEST GERMANY

Attn: W. Morell

Motor Columbus

Parkstrasse 27

CH- 5401

Baden

SWITZERLAND

Attn: H. Fuchs 
Metional Wuclear Corporation

Cambridge Road, Whetstone

Leicester LE8 3LS?

ENGLAND

Attn: A. D. Hayward

J. V. Tindale

woK $A G$ Baden

Beznau vuclear Power Plant

CH-5312 Doettingen

SWITZERLAND

Attn: 0. Tatti

Norsk Kabelfabrik

3000 Dramen

WOBWAY

Attn: C. T. Jacobsen

Nuclear Power Engineering Test Center 6-2, Toranomon, 3-Chome

Minato-ku, \#2 Akiyana Bldg.

Tokyo 105

JAPAN

Attn: K. Takumi

Ontario Hydro

700 University Avenue

Toronto, Ontario M5G $1 \times 6$

CANADA

Attn:

R. Wong

B. Kukreti

Oy Strombers Ab

Helsinki Works

Box 118

FI-00101 Helsinki 10

E INLAND

Attn: P. Paloniemi

Radiation Center of Osaka Prefecture

Radiation ApplicationPhysics Division

Shinke-Cho, Sakai

Osaka, 593, JAPAN

Attn: $S$. Okamoto

\section{Rappinl}

EUEA-PEC

Via Arcoveggio $56 / 23$

Bologna

ITALY

Attn: Ing. Ruggero
Rhe inisch-Westfallscher

Technischer Uberwachunge-Vereln e.v.

Postfach $10 \quad 32 \quad 61$

D-4300 Essen 1

WEST GERKANYY

Attn: R. Sartori

\section{Sydkraft}

Southern Sweden Power Supply

21701 Malmo

SWEDEX

Attn: 0 . Grondalen

Technical University Munich

Institut for Radiochemie

D-8046 Garching

WEST GERMANY

Attn: Dr. H. Heusinger

UKAEA

Materials Development Division

Building 47

AERE Harwell

OXON OXII ORA

ENGLAND

Attn: D. C. Phillips

United Kingdom Atomic Energy Authority

Safety \& Reliability Directorate

Wigshaw Lane

Culcheth

Warrington WA3 $4 \mathrm{NE}$

ENGLAND

Attn: M. A. H, G. Alderson

Waseda University

Department of Electrical Engineering

3-4-1 Ohkubo, Shinjuku-ku

Tokyo 160

JAPAN

Attn: $Y$. Ohki 
$1200 \mathrm{~J}$. P. VanDevender

1800 R. L. Schwoebel

1810 R. G. Kepler

1811 R. L. Clough

1812 J. M. Zeigler

1812 K. T. Gillen

1813 J. G. Curro

6200 V. L. Dugan

6300 R. W. Lynch

6400 A. W. Snyder

$6410 \mathrm{~J}$. W. Hickman

6417 D. D. Carlson

6420 J. V. Walker

6433 F. V. Thome

6440 D. A. Dahlgren

6442 W. A. Von Riesemann

6444 L. D. Buxton

6446 L. L. Bonzon (20)

6446 W. H. Buckalew

6446 L. D. Bustard

6446 J.W. Grossman

6446 M. J. Jacobus

6446 J. D. Keck

6446 F. J. Wyant

6447 D. L. Berry

6449 K. D. Bergeron

$6450 \mathrm{~J}$. A. Reuscher

8024 P. W. Dean

3141 S. A. Landenberger (5)

3151 W. L. Garner 


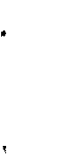




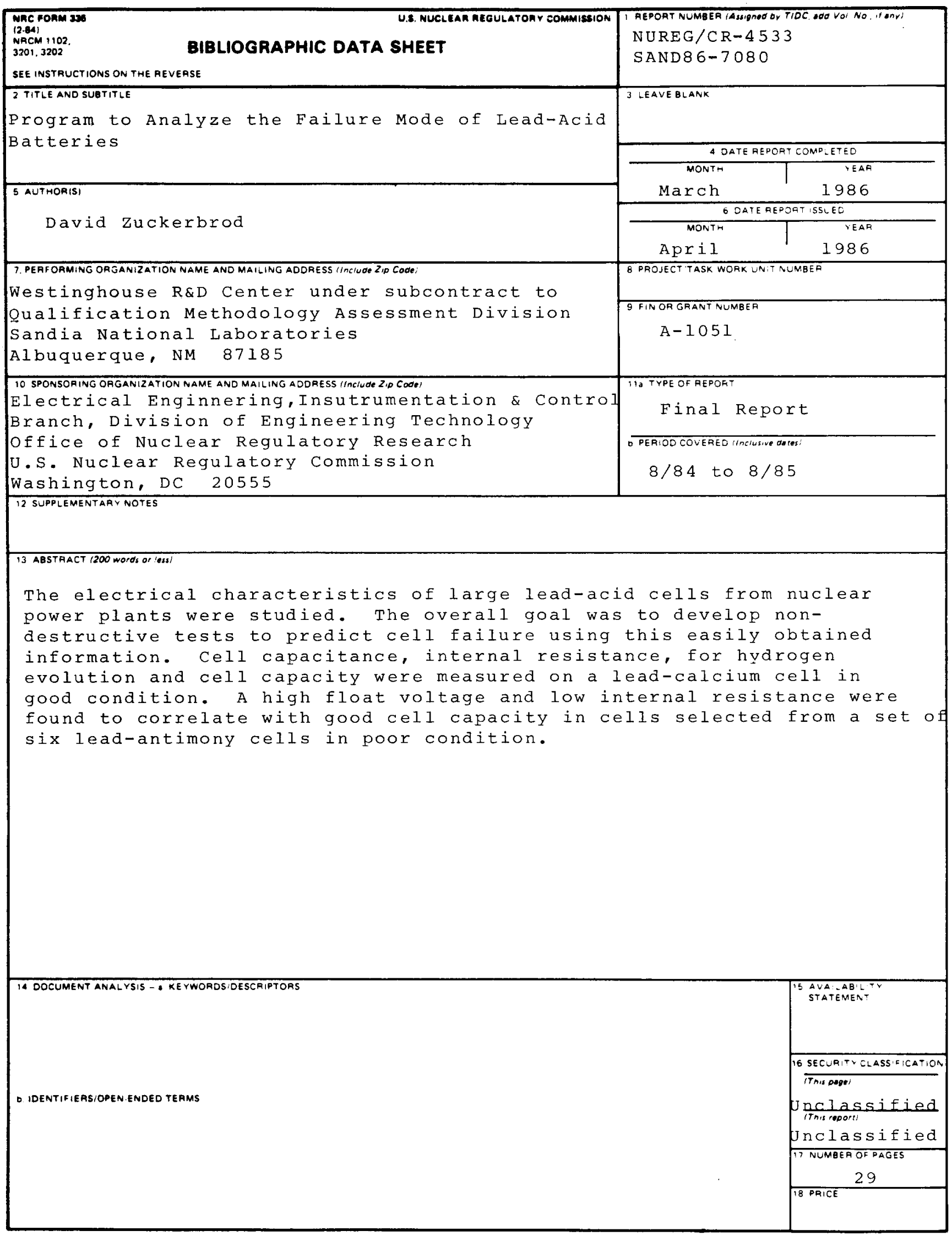

